\title{
Technology Orientation and Inbound Open Innovation at LMT Firms: An Empirical Study in Sri Lanka
}

\author{
M.M.D.R. Deegahawature ${ }^{1}$ \\ ${ }^{1}$ Department of Industrial Management \\ Faculty of Applied Sciences \\ Wayamba University of Sri Lanka \\ Kuliyapitiya \\ SRI LANKA \\ dharsana@wyb.ac.lk ${ }^{1}$
}

\begin{abstract}
Despite the growing interest in open innovation, previous studies have ignored the role of firms' strategic capability in evoking open innovation, especially in low and medium-low technology (LMT) firms from technologically less advanced countries. This study rectifies this problem by examining the impact of technology orientation on the implementation of inbound open innovation. Also, assessing the effect of the environment on the relationship between technology orientation and inbound open innovation, this study considers technology turbulence and market potential. The hierarchical regression analysis, based on cross-sectional survey data collected from 272 LMT firms in Sri Lanka reveals that LMT firms adopt inbound open innovation at a moderate level. LMT firms value technology and face above-average level technology turbulence and market potential. Results show that both technology orientation and market potential have a significant positive effect on the implementation of inbound open innovation, but no evidence from technology turbulence. Also, technology turbulence negatively, and market potential positively moderate the relationship between technology orientation and inbound open innovation. The findings indicate that LMT firms in Sri Lanka should exploit technologically superior products to meet customers' needs and attract the market. Also, technology orientation plays a salient role in attractive markets but not in technologically turbulent environments.
\end{abstract}

Keywords: Technology orientation, Technology turbulence, Market potential, Inbound open innovation.

\section{INTRODUCTION}

During the latter part of the twentieth century, the innovation landscape underwent a drastic change due to the growing mobility of highly experienced and skilled workers, presence of private venture capitals, shorten time to market (Chesbrough, 2006a), short innovation and product life cycles, the rising cost of research and development (R\&D), the dearth of resources, etc. (Drechsler \& Natter, 2012). Those changes caused to erode the underpinnings of closed innovation and emerge open innovation (Chesbrough, 2006a). The firms implement closed innovation by strictly controlling R\&D activities. Contrary to that, open innovation 
works through cooperating with outside firms over more porous organizational boundaries. Thus the way, the firms manage innovation and commercialize knowledge, underwent a fundamental shift (Chesbrough, 2003; Chesbrough, 2006a).

The resource-based view highlights that the firms apply assets and capabilities to achieve competitive advantages (Hunt \& Morgan, 1995). Prior researches also show distinctive capability can promote innovation (Zhou, Yim, \& Tse, 2005) and generate competitive advantages (Barney, 1991; Zhou et al., 2005). Irrespective of its reliability and validity, a few studies focus on the role of capabilities in implementing open innovation. Though the present literature discusses the effect of some capabilities such as absorptive and desorptive capabilities, a few studies have inquired about the effect of strategic capabilities on open innovation (i.e. Deegahawature, 2014b; 2014c).

On the other hand, open innovation studies lack in certain contexts though the scholars' speculate that open innovation applies across firms and countries irrespective of their technology and R\&D intensity (Chesbrough \& Crowther, 2006; Santamaría, Nieto, \& Barge-Gil, 2009). Many studies focus on hightech firms and ignore low and medium-low technology (LMT) firms (Heidenreich, 2009; Santamaría et al., 2009; Vrande, Jong, Vanhaverbeke, \& Rochemont, 2009). West and Bogers (2017) also highlight the need for investigating open innovation in different firms such as small, new, and not-for-profit firms. Though there are a few open innovation studies (Hossain \& Kauranen, 2016, Santoro, Ferraris, Giacosa, \& Giovando, 2018), yet the open innovation at small and medium-sized enterprises is to be investigated (Hossain, Islam, Sayeed, \& Kauranen, 2016). Thus, limited studies on LMT firms appeal to this study (i.e. Deegahawature, 2014b, 2014c; Santamaría at al., 2009; Robertson, Smith, \& von Tunzelmann, 2009). Further, many studies focus on the context of developed, technologically advanced economies (Karo \& Kattel, 2010), and emerging economies (i.e. Kafouros \& Forsana, 2012; Lee, Park, Yoon, \& Park, 2010; Li \& Kozhikode, 2009). However, except in a few studies (i.e. Deegahawature 2014a, 2014b, 2014c), open innovation literature largely neglected technologically less advanced countries. After reviewing the open innovation literature, Hossain et al. (2016) identify the contexts of developing countries and beyond high-tech industries as an avenue for future studies.

Aimed at filling this gap, this study attempts to explain how strategic orientation affects open innovation. Particularly, this study focuses on the role of technology orientation in implementing inbound open innovation at LMT firms in technologically less advanced countries. Also, environmental uncertainty stimulates changes in business strategies. Thus, this study considers the external environment to further assess how technology turbulence and market potential moderate the effect of technology orientation over inbound open 
innovation. This study contributes to the present literature in three ways. Firstly, it helps to understand inbound open innovation at LMT firms in technologically less advanced countries, and their trend towards the technology orientation. Secondly, it promotes to comprehend the effect of capabilities on implementing inbound open innovation in low technology and low R\&D intensity contexts. Consequently, it broadens our understanding of the role of technology orientation in open innovation. Finally, it deepens our knowledge on the effect of the external environment on open innovation implementation and technology orientation in the selected context.

This paper has been arranged as follows. The next section reviews the relevant literature on open innovation, technology orientation, technology turbulence, and market potential, and develops study hypotheses. The third section describes the methodology employed in this study. The fourth section reports and discusses the analysis and results of the empirical study, whereas the final section outlines the discussion, conclusions, and directions for future studies.

\section{LITERATURE REVIEW AND HYPOTHESES}

"Most innovations fail. Companies that don't innovate die" (Chesbrough, 2006a, p. xvii). It emphasizes innovation and its close link with firms' performance. Innovation plays a significant role at different levels such as global, national, firm, group, and individual (Herzog, 2011; West,
Vanhaverbeke, \& Chesbrough, 2006). At the firm level, it impels firm growth and sustainability (Elmquist, Fredberg, \& Ollila, 2009) and enhances organizational competitiveness and success (Edwards, Battisti, McClendon Jnr, Denyer, \& Neely, 2005; Essmann \& Preez, 2009; Smith, Busi, Ball, \& Meer, 2008).

The OECD (2005, p.46) defined innovation as "the implementation of a new or significantly improved product (good or service), or a process, a new marketing method, or a new organizational method in business practices, workplace organization or external relations". Innovation exists in any new or significantly improved product, process, marketing method, and organizational method. Technological innovation alone has a limited effect on firm performance, thus firms should also innovate in terms of organizationally to create appropriate business models (Kolk \& Püümann, 2008).

Chesbrough (2006a) highlights that the firms need to change the way they generate and commercialize new ideas. Accordingly, prior research used a linear innovation model, called closed innovation assuming innovation is a product of internal R\&D efforts. Closed innovation believes in internal innovations, investing heavily on resources in internal R\&D departments (OECD, 2008). In contrast, open innovation focuses on linking with outside firms over the more porous organizational boundaries. Open innovation refers to the "use of purposive inflows and 
outflows of knowledge to accelerate internal innovation, and expand the markets for external use of innovation, respectively. Open Innovation assumes that firms generate new ideas by using internal and external means, and commercializes them by internal and external paths, as the firms look to advance their technology" (Chesbrough, 2006b, p. 1).

A firm can link with external firms by adapting inbound and outbound open innovation. Accordingly, this study distinguishes two open innovation strategies. Inbound open innovation uses purposive inflows of knowledge/ technology to enable firms to acquire new knowledge and competencies, whereas outbound open innovation uses purposive outflows of knowledge to commercialize the technology enabling firms to seek out different paths to market. The former uses external technologies to advance internal innovation while the latter uses external pathways to commercialize internal technologies. This study focuses on outbound open innovation.

Firm performance depends on both opportunities and resources. As pointed out earlier, resources consist of assets and capabilities. This study distinguishes capabilities from other resources, and defines it as a "firmspecific resource - an organizationally embedded nontransferable resource which contributes to improve the productivity of other resources possessed by the firm" (Makadok, 2001, p. 389). Firms can only build capabilities (Teece, Pisano, \& Shuen,
1997). As the resource-based view suggests, distinctive capabilities bring competitive advantages to firms. On the other hand, according to the dynamic capability perspective, firms should have an "ability to integrate, build and reconfigure internal and external competencies to address rapidly changing environment" (Teece et al., 1997, p. 516). Firms equipped with dynamic capabilities will respond to the erosion factors, which undermine closed innovation and promote open innovation, and finally, adopt open innovation. Among various capabilities, strategic orientation counts for innovation (Zhou et al., 2005).

Previous studies establish a causal link between strategic orientation and innovation (i.e. Bryan, 1999; Kumar, Boesso, Favotto, \& Menini, 2012; Matsuno \& Mentzer, 2000). Strategic orientation focuses on some principles that direct and influence a firm to generate intended behavior (Hakala, 2011; Hakala \& Kohtamäki, 2011). These principles guide the firm to conduct its business with deeply rooted values and beliefs that motivate the firm to achieve superior performance (Gatignon \& Xuereb, 1997). And technology orientation can represent strategic capabilities (Gatignon \& Xuereb, 1997; Salavou, Baltas, \& Lioukas, 2004; Zhou et al., 2005; Hakala, 2011).

Technology orientation reflects the inclination of a firm towards introducing or using new technologies, products, and innovations (Gatignon \& Xuereb, 1997; Hult, Ketchen, \& Slater, 2005). This adapts the 'technology pull' 
strategy and assumes that customers prefer technologically superior products or services (Zhou et al., 2005). Two significant features of technology-oriented firms include: their willingness to acquire new technologies and apply state-of-theart technologies. Thereby, such firms achieve product differentiation or cost advantages to satisfy and attract customers (Gatignon \& Xuereb, 1997). Creativity and inventions become norms and values guiding the activities and strategies of the technology-oriented firms. Thus, such firms are proactive in acquiring new technologies and applying the latest sophisticated technologies in product developments (Gatignon \& Xuereb, 1997). When attempting to acquire new technologies, they may willingly turn to outside since by default, LMT firms are weak in internal knowledge creation by R\&D. Thus, a technologyoriented firm may prefer inbound open innovation through acquiring and using state-of-the-art technologies. Based on this argument, the theoretical speculations of the resource-based view and dynamic capability perspective, this study postulates the following hypothesis.

H1: Technology orientation has a positive effect on implementing inbound open innovation.

\section{Turbulent Environment:}

Environmental turbulence reflects the magnitude of change in the elements of environment. A dynamic, threatening, and complex environment is challenging the traditional approaches of management (Davis, Morris, \& Allen, 1991). Due to the implications of a turbulent environment, firms tend to learn new ways to do business and compete (Davis et al., 1991) and create new strategies. The uncertainty created by the turbulent environment stimulates firms to change present strategies and be innovative in management approaches (Ettlie, 1983). The present study focuses on two aspects of environment turbulence: technology turbulence and market potential. Technology turbulence refers to the speed of change and unpredictability of technology in an industry environment (Jaworski \& Kohli, 1993). Market potential indicates the extent of attractiveness of the market place, and is characterized by growth in customer demand and size (Song \& Parry, 1997). A highly turbulent environment in terms of technology and market potential creates opportunities and challenges. Firms may change their present business strategies to utilize opportunities and face challenges, and finally to retain and sustain in the market (Ettlie, 1983; Li \& Calantone, 1998). But some erosion factors such as high technology turbulence and difficulty in adapting to the rapid changes inhibit closed innovation and promote open innovation. Higher market potential spurs faster innovation resulting in higher market share and profit growth (Acemoglu \& Linn, 2004; Song \& Parry, 1997). Growing market demands firms to use new sophisticated knowledge to meet growing current and especially, latent needs of customers. LMT firms lack internally created knowledge due to weak R\&D intensity, and therefore, have to rely on external knowledge sources. Thus, firms in a more technologically turbulent 
environment and having higher market potential may tend to adopt inbound open innovation. Thus, this study postulates the following hypotheses.

H2: Technology turbulence has a positive effect on implementing inbound open innovation.

H3: Market potential has a positive effect on implementing inbound open innovation.

The turbulent environment in terms of technology and market potential creates opportunities for the firms. This helps firms enhance their customer base by meeting their current and future latent needs. Customers in a turbulent environment change their product preference and consistently seek new products, and firms appeal to potential customers and maintain current customers with new and upgraded products (Hanvanich, Sivakumar, \& Hult, 2006). Firms' survival in such an environment, therefore, depends on the firms' ability to respond to the varying requirements of present and potential customers. Technologyoriented firms in turbulent environments incline to introduce and use new technologies, products, and innovations. Due to weak internal R\&D capacity, LMT firms have to seek external knowledge sources to handle the changing technology requirements. Thus, technology orientation has a stronger effect on inbound open innovation in a technologically turbulent environment. In an attractive market, LMT firms need new knowledge to capture growing customer demand and market share. Particularly, they may need such knowledge to meet the current and latent needs of customers in attractive growing markets. Thus, technology orientation may have a stronger effect on inbound open innovation in a highly potential market. Therefore, the study postulates the following hypotheses.

H4: Technology turbulence positively moderates the relationship between technology orientation and implementing inbound open innovation.

H5: Market potential positively moderates the relationship between technology orientation and implementing inbound open innovation.

\section{METHODOLOGY}

\subsection{Sample and Data Collection}

This study aims to investigate the effect of technology orientation, technology turbulence, and market potential on implementing inbound open innovation, and evaluate the moderating effect of technology turbulence and market potential focusing on LMT firms in technologically less advanced countries. LMT firms in Sri Lanka were selected as the empirical setting.

This study collected data through a questionnaire based on the crosssectional survey method. In accordance with OECD categorization of industries, five industries out of nine in the LMT category (Hatzichronoglou, 1997; Hirsch-Kreinsen, 2008) were selected based on the number of firms in the industry. Selected industries were Rubber and plastics products, Basic 
metals and fabricated metal products, Wood, pulp, paper, paper products, printing and publishing, Food products, beverages and tobacco, Textiles, textile products, leather, and footwear. Other industries were dropped due to a lower number of firms. This study selected 660 firms employing 25 or more employees as the sample by proportionate stratified random sampling method (population was 2,496 firms). Allowing for a 50 percent non-response and rejection rate, the study planned to gather 330 responses. However, only 312 firms responded (yielding 47.3 percent response rate), and 40 responses were discarded due to incompletion. Finally, 272 useable questionnaires were retained for the analysis (yielding 41.2 percent net response rate).

\subsection{Variables and Measures}

This research uses reflective measures to operationalize constructs. The measure of technology orientation was adapted from Zhou et al. (2005) who developed it based on Gatignon and Xuereb (1997), and Hurley and Hult (1998). Several studies have used and validated this scale in innovation (i.e. Gatignon \& Xuereb, 1997; Zhou et al., 2005). This scale consists of four items, and captures the inclination of a firm towards introducing and using new technologies, products, and innovation. The measure of technology turbulence was derived from Zhou and $\mathrm{Wu}$ (2010) who developed it based on Jaworski and Kohli (1993). Using four items, this scale measures the extent to which the technology in an industry varies. This scale is appropriate since the same has been used in several open innovation studies (i.e. Hung \& Chiang, 2010; Lichtenthaler, 2009). The measure of market potential was adapted from Song and Parry (1997), and it captures the extent of attractiveness of the market in terms of growth in customer demand and size. Previous open innovative studies have used this fouritem scale (i.e. Hung \& Chiang, 2010). A seven-point Likert scale ranging from 1 = "strongly disagree" to 7 = "strongly agree" captured the responses. Also, the extent of implementing inbound open innovation was measured by adapting the procedure of Laursen and Salter (2006). Finally, this study converted it to a 10-point index where one indicates 'use of no inbound open innovation strategy' while ten indicates 'use of inbound open innovation strategy at the highest degree'.

Construct Validity: This study adapted Anderson and Gerbing (1988)'s two-step approach to refine and assess construct validity. Firstly, exploratory factor analysis was used to assess the multi-item scales (technology orientation, technology turbulence, and market potential). Communalities of all items exceeded the cutoff point of 0.50 (Hair, Black, Babin, \& Anderson, 2009). Also, the factor loadings of all items were adequately higher than the theoretically expected valve (minimum was 0.81). Thus, all items were retained after the exploratory factor analysis. Secondly, confirmatory factor analysis was run for all focal variables. After deleting one item due to higher cross-loading, 
the measurement model achieved a satisfactory fit to the data $\left(\chi^{2}[41]=\right.$ 221.65, $\mathrm{p}<.001$; goodness-of-fit index $[\mathrm{GFI}]=0.89$, root mean square residual $[R M R]=0.06$; incremental fit index $[\mathrm{IFI}]=0.96$, normed fit index $[\mathrm{NFI}]=0.95$, comparative fit index $[\mathrm{CFI}]=0.96)$. All factor loadings were statistically significant $(\mathrm{p}<$ $.001)$. The composite reliability of each construct measure (over 0.86) exceeded the minimum threshold point of 0.60 (Bagozzi \& Yi, 1988). Also, the average variance extracted (AVE) of all constructs $(0.78-0.91)$ was well above the minimum cut-offpoint of 0.50 (Hair et al., 2009). Thus, the results confirmed adequate convergent validity and reliability of each construct (Fornell \& Larcker, 1981).

Table 1. Basic Descriptive Statistics and Correlations

\begin{tabular}{lccccccc}
\hline Variable & Mean & SD & 1 & 2 & 3 & 4 & 5 \\
\hline 1. Inbound open innovation & 5.69 & 1.80 & 1 & & & & \\
2. Technology orientation & 5.12 & 1.28 & $.54^{* *}$ & 1 & & & \\
3. Technology turbulence & 4.48 & 1.17 & $.45^{* *}$ & $.66^{* *}$ & 1 & & \\
4. Market potential & 4.60 & 1.06 & $.49^{* *}$ & $.58^{* *}$ & $.76^{* *}$ & 1 & \\
5. Firm age & 17 & 9 & $.14^{*}$ & .11 & $.13^{*}$ & $.24^{* *}$ & 1 \\
6. Firm size & 107 & 365 & .10 & $.17^{* *}$ & $.17^{* *}$ & $.17^{* *}$ & $.20^{* *}$ \\
\hline
\end{tabular}

Notes: $\quad N=272 ; * * p<0.01, * p<0.05$

Discriminant validity of the measures was tested by calculating the shared variance between all possible pairs of the construct, and then comparing them with AVE to determine whether they were lower than the AVE of the individual constructs (Fornell \& Larcker 1981). Results show that all AVE values $(0.78-0.91)$ were sufficiently higher than the shared variance with other constructs $(0.34-$ 0.55), supporting the discriminant validity. Accordingly, the results confirm adequate reliability and validity of the measures.

Also, the study considered two control variables focusing on the characteristics of the firms: firm age and firm size. The number of years from the start of the business was used to measure firm age. Firm age ranged from 1 to 60 years. 25 percent of the firms were below 11 years of age while 25 percent were above 22 years of age. Firm size was determined by the number of employees in the firm. The number of employees in the firm ranged from 25 to 6000.25 percent of the firms in the sample employed 42 employees while 25 percent of the firms employed over 95 employees.

\section{ANALYSIS AND RESULTS}

Table 1 presents descriptive statistics and correlations of focal variables. Results show that LMT firms in technologically less advanced countries adopt inbound open innovation at a moderate level $(M=$ 5.69, $S D=1.80)$. LMT firms demonstrate a moderate level of technology orientation $(M=5.12, S D$ $=1.28)$. Also, they face an aboveaverage level of environment 
turbulence (technology turbulence: $M$ $=4.48, S D=1.17$; market potential: $M$ $=4.60, S D=1.06)$. Results indicate that 13 correlations out of 15 are positive and significant. Also, technology orientation, technology turbulence, and market potential show a significant positive association with inbound open innovation $(p<.01)$, supporting the posited relationships. Both technology turbulence and market potential are positively and significantly associated with technology orientation $(p<.01)$. Though the firm age is positively and significantly associated with inbound open innovation $(p<.05)$, firm size has an insignificant effect on inbound open innovation $(p=.103)$.

The present study employed the hierarchical regression analysis to test hypotheses and assess the explanatory power of each variable (Aiken \&
West, 1991). This method is appropriate since it can explain whether interaction terms have significant effects over and above the direct effect, and thereby the existence of interaction effect (Wiklund \& Shepherd, 2003). The scales, which were used to test the interaction effect, were mean-centered aiming at alleviating the possible effect of multicollinearity and explaining the effect of interaction terms (Aiken \& West, 1991). The effect of multicollinearity was tested by the variance inflation factor (VIF), and calculated for all constructs in each regression model. The maximum VIF value within the models was 3.59 , and it is far below the threshold value of 10 (Neter, Wasserman, \& Kutner, 1990). Thus, the results alleviate the issue of multicollinearity. The results of the hierarchical regression analysis are presented in Table 2.

Table 2. Results of Hierarchical Regression Analysis

\begin{tabular}{|c|c|c|c|c|c|c|}
\hline \multirow[t]{2}{*}{ Variables } & \multicolumn{2}{|c|}{ Mode1 1} & \multicolumn{2}{|l|}{ Mode1 2} & \multicolumn{2}{|l|}{ Mode1 3} \\
\hline & $b(s . e)^{a}$ & $\beta$ & $\mathrm{b}(\mathrm{s} \cdot \mathrm{e})^{\mathrm{a}}$ & $\beta$ & $b(s . e)^{a}$ & $\beta$ \\
\hline \multicolumn{7}{|l|}{ Contro1 Variables } \\
\hline Firm age & $.03(.01)$ & $.13^{\circ}$ & $.01(.01)$ & .04 & $.01(.01)$ & .07 \\
\hline Firm size & $.00(.00)$ & .07 & $-8.91 \mathrm{E}-5(.00)$ & -.02 & $-8.40 \mathrm{E}-5(.00)$ & -.17 \\
\hline \multicolumn{7}{|l|}{ Direct Variables } \\
\hline $\begin{array}{l}\text { Technology } \\
\text { orientation }\end{array}$ & & & $.56(.09)$ & $40^{*+*}$ & $.54(.10)$ & $.39^{*+4}$ \\
\hline $\begin{array}{l}\text { Technology } \\
\text { turbulence }\end{array}$ & & & $-.03(.13)$ & -.02 & $-.24(.14)$ & -.15 \\
\hline Market potential & & & $.45(.14)$ & $27^{*+*}$ & $.66(.15)$ & $.39^{-44}$ \\
\hline \multicolumn{7}{|l|}{ Interaction effects } \\
\hline $\begin{array}{l}\text { Technology } \\
\text { orientation } \times \\
\text { Technology turbulence }\end{array}$ & & & & & $-.29(.10)$ & $-.22^{* *}$ \\
\hline $\begin{array}{l}\text { Technology } \\
\text { orientation } \times \\
\text { Market potential }\end{array}$ & & & & & $.26(.10)$ & $.19^{* \bullet}$ \\
\hline$R$ & .16 & & .59 & & .60 & \\
\hline$R^{2}$ & .03 & & .34 & & .37 & \\
\hline$\Delta R^{2}$ & .03 & & .31 & & .03 & \\
\hline$R^{2}(a d j)$ & .02 & & .33 & & .35 & \\
\hline$F$ & $3.53^{\circ}$ & & $27.61^{* *}$ & & $21.76^{* \bullet}$ & \\
\hline
\end{tabular}

Note: Dependent variable: Inbound open innovation; $\mathrm{N}=272 ; * * * \mathrm{p}<.001, * * \mathrm{p}<.01,{ }^{*} \mathrm{p}<.05$

${ }^{a}$ Unstandardized coefficients with standard errors in the parentheses and standardized coefficients are reported 
Model 1 includes control variables only. Firm age shows a significant positive effect on implementing inbound open innovation $(\beta=0.13, p$ $<.05)$, but no significant effect from firm size $(\beta=0.07, p=.23)$. Control variables account for only 3 percent variance in implementing inbound open innovation $\left(\mathrm{R}^{2}=0.03, p<.05\right)$. In model 2, the effect of direct variables is considered. Both technology orientation $(\beta=0.40, p<$ $.001)$ and market potential $(\beta=0.27, p$ $<.001)$ indicate significant and positive effects on inbound open innovation, but no significant effect from technology turbulence $(\beta=-$ $0.02, p=.80)$. This results support hypothesis 1 and hypothesis 3 . However, results do not support hypothesis 2 . Adding direct variables increases the R-squared significantly, indicating that direct variables explain a significant level of variance in implementing inbound open innovation $\left(\mathrm{R}^{2}=0.34, \Delta \mathrm{R}^{2}=0.31, p<\right.$ .001). Model 3 considers the interaction effect of environment turbulence: technology turbulence and market potential. The results show that technology turbulence has a significant negative moderating effect $(\beta=-0.22, p<.01)$, contrary to the hypothesis 4 . The results indicate that market orientation has significant positive moderation effect $(\beta=0.19, p$ $<.01)$. This supports hypothesis 5 . However, interaction terms account for only 4 percent of variance in implementing inbound open innovation $\left(\mathrm{R}^{2}=0.37, \Delta \mathrm{R}^{2}=0.04, p<\right.$ $.001)$. Adjusted $\mathrm{R}^{2}$ increases gradually from model 1 to 3 , indicating that each model has a significant influence on the dependent variable even after considering the effect of other variables in the model (Tarling, 2009).

\section{DISCUSSION AND CONCLUSION}

Yet, open innovation in LMT firms and technologically less advanced countries has been less researched. Though prior literature has investigated several antecedent conditions for open innovation, they ignored the role of strategic capabilities in implementing open innovation. This study attempts to bridge this gap by investigating the effect of technology orientation on implementing inbound open innovation. Drawing on resourcebased view and dynamic capability perspective, this research posits a positive causal link between capabilities and implementing inbound open innovation. Also, this study considers the role of environment turbulence by investigating the effect of technology turbulence and market potential, and consider their moderating effect.

\section{Theoretical Contributions}

Present study extends innovation literature in several ways. Firstly, this article broadens our knowledge about open innovation endeavors of LMT firms in technologically less advanced countries, and the effect of both firm age and firm size. The findings reveal that LMT firms in technologically less advanced countries are moderately inclined to inbound open innovation. This supports the scholars' speculation that open innovation counts across firms and countries irrespective of their technology and R\&D intensity (Chesbrough \& Crowther, 2006; Santamaría et al., 
2009), and at present, it is a global trend (Hung \& Chiang, 2010). Also, results show that LMT firms are technology-oriented and thereby, proactive in acquiring and using new and sophisticated technologies, products, and innovations. Technology orientation in LMT firms in technologically less advanced countries is comparable to the same in China's emerging economy (Zhou et al., 2005). Results show that technology turbulence in LMT industries in Sri Lanka equal to that in medium and large industries in Germany, Austria, and Switzerland (Lichtenthaler, 2009), and it even exceeds Taiwanese electronic manufacturing firms (Hung \& Chiang, 2010). Though LMT firms have attractive market potential, it is lower to the same in Taiwanese electronic manufacturing firms (Hung \& Chiang, 2010). Compared to the high-tech firms in electronic, information technology and telecommunication industries in China, LMT firms in Sri Lanka mark relatively lower technology turbulence and market potential (Zhou \& Wu, 2010). Further, the findings reveal that firm age influence implementing inbound open innovation. Older firms prefer open innovation than young firms. However, firm size shows an insignificant influence.

Secondly, present study adds to innovation literature by investigating technology orientation as an antecedent condition to inbound open innovation. Technology orientation shows an influential effect. Firms introducing and using sophisticated technologies in their development endeavors are more inclined to inbound open innovation. Accordingly, this finding confirms the reliability and validity of capability perspective in inbound open innovation, particularly firms' capability to satisfy the customers who seek technologically improved products. Since LMT firms are lagging in internally developed knowledge by $\mathrm{R} \& \mathrm{D}$, they have to depend on the external knowledge to meet the growing and changing demand of current and potential customers for technologically superior products. Thus, confirming the theoretical speculations, the results suggest that technology orientation influence firm strategy - a pivotal resource in implementing inbound open innovation. Investigating the market orientation and open innovation, Arrigo (2018) concluded that market driven firms are inclined towards open innovation. This finding is in line with the previous finding that technology orientation positively influences the firm-performance (Masa'deh, Al-Henzab, Tarhini, \& Obeidat, 2018).

Thirdly, this study widens our understanding about the influence of environment on open innovation by examining the effect of technology turbulence and market potential. The environment factors show inconsistent results. Technology turbulence shows a negative but insignificant effect while market potential shows a high positive effect on inbound open innovation. This may be attributed to frequent changes in technology increasing the cost of LMT firms in terms of accessing external technology assets (Lee et al., 2010). Also, in a turbulent environment, 
firms face certain unfavorable situations creating threats such as smaller decision windows, changing decision constituencies, lack of predictable technology resource needs, etc. (Davis et al., 1991). LMT firms may be unable to cope with those threats since technology turbulence demands to acquire dissimilar knowledge from other sources. However, LMT firms may be immune to those unfavorable conditions since highly potential markets create opportunities. Opportunities created by attractive markets increase the need for new technological knowhow to satisfy customers' evolving current and latent needs, making LMT firms turn to external sources of knowledge. This explains the different influences of various unstable environments on inbound open innovation. Also, higher market potential increases the inclination of LMT firms towards inbound open innovation.

Fourthly, this study broadens our understanding of how environment factors moderate the effect of technology orientation on implementing inbound open innovation. The findings strongly suggest that the relationship between technology orientation and implementing inbound open innovation is weakened by increasing technology turbulence, and strengthened by increasing market potential. Technology orientation has a stronger effect in a technologically stable environment because an unfavorable turbulent environment discourages LMT firms to handle the threats. Also, opportunities created by highly attractive market spur LMT firms to introduce and use new technologies and innovation to satisfy the evolving present and latent customer demand by creating new products.

Finally, this study adds to the open innovation literature by testing the proposed model with data from LMT firms in technologically less advanced countries. Many open innovation research focuses on high-tech firms (Heidenreich, 2009; Santamaría et al., 2009) and technologically advanced, developed countries (Karo \& Kattel, 2010) and emerging economies (Kafouros \& Forsans, 2012; Li \& Kozhikode, 2009), limiting the generalizability of the findings despite the scholars' claim that open innovation is applicable across the firms and countries irrespective of their dissimilarities. The unique characteristics of LMT firms in technologically less advanced countries may enrich the open innovation theories. The findings confirm that irrespective of its originated context, the resource-based view work in LMT firms in technologically less advanced countries. Also, it confirms the effect of environment on strategic choice.

\section{Managerial Implications}

The study provides several managerial implications for LMT firms to facilitate implementing inbound open innovation. First, the findings provide empirical evidence that LMT firms in technologically less advanced countries adopting open innovation may implement and benefit from inbound open innovation - a feasible strategy in LMT firms. Second, technology orientation in LMT firms 
indicates that customers desire to learn and try products embedded with new features that offer unique experience over existing products. This encourages LMT firms to introduce creative products rather than merely responding to customer preference. Third, the results suggest that firms can foster inbound open innovation by promoting technology orientation. Also, managers may understand the role of technology orientation in achieving competitive advantages. Fourth, the findings warn managers implementing inbound open innovation to consider the effect of environment. LMT firms would like to adopt inbound open innovation in an attractive market. Finally, findings show the different effects of the environmental factors, thus LMT firms should consider different environmental conditions. Firms' ability to respond to the customers' preference for technologically superior products or services is hindered by technological instability but is spurred by an attractive market with growth opportunities.

\section{Limitations and Further Research}

This study has several limitations that demand further investigations. First, this study focuses mainly on technology orientation and inbound open innovation. Further research can expand the present study by adding other capabilities - market orientation, entrepreneurial orientation, learning orientation, political and business ties, and outbound innovation. The collective effect of capabilities deserves our attention. Also, this study can be improved by incorporating the firms' assets such as physical resources.
Second, this study concentrates on environmental effect by considering only technology turbulence and market potential. It opens further research opportunities to consider the effect of other environmental conditions such as the government support, the intensity of competitive rivalry, industry characteristics and national culture. Third, the empirical findings are based on firms in five LMT industries (out of nine) in Sri Lanka. This study leaves out dissimilarities across the LMT industries, low-and-medium-low technology industry categories, and countries. However, the unique characteristics of industries, industry categories and countries may influence the present findings. This limits the generalizability of the findings and opens further research opportunities for cross-industry, cross-industry-category, and crosscountry studies. Finally, this study postulates a causation mechanism from technology orientation as a strategic capability for implementing inbound open innovation. Though research in this nature prefers a longitudinal approach, this study adopted cross-sectional approach. Thus, the author appeals for additional longitudinal research design.

\section{REFERENCES}

Acemoglu, D., \& Linn, J. (2004). Market size in innovation: Theory and evidence from the pharmaceutical industry. Quarterly Journal of Economics, 119(3), 1049-1090.

Aiken, L. S., \& West, S. G. (1991). Multiple regression testing and interpreting interactions. 
Newbury Park, CA: SAGE Publications.

Anderson, J. C., \& Gerbing, D. W. (1988). Structural equation modeling in practice: A review and recommended two-step approach. Psychological Bulletin, 103(3), 411-423.

Arrigo, E. (2018). Open innovation and market orientation: an analysis of the relationship. Journal of the Knowledge Economy, 9(1), 150161.

Bagozzi, R. R., \& Yi, Y. (1988). On the evaluation of structural equation models. Journal of the Academy of Marketing Science, 16 (2), 74-94.

Barney, J. (1991). Firm resources and sustained competitive advantages. Journal of Management, 17(1), 99120.

Bryan, A. L. (1999). Strategic type, market orientation, and the balance between adaptability and adaptation. Journal of Business Research, 45(2), 147-56.

Chesbrough, H. (2006a). Open innovation: The new imperative for creating and profiting from technology. Boston, Massachusetts: Harvard Business School Press.

Chesbrough, H. (2006b). Open innovation: A new paradigm for understanding industrial innovation. In H. Chesbrough, W. Vanhave, \& J. West, Open innovation: Researching a new paradigm (pp. 1-12). Oxford: Oxford University Press.

Chesbrough, H., \& Crowther, A. K. (2006). Beyond high-tech: Early adopters of open innovation in other industries. $R \& D$ Management, 36(3), 229-236.

Davis, D., Morris, M., \& Allen, J. (1991). Perceived environmental turbulence and its effect on selected entrepreneurship, marketing, and organizational characteristics in industrial firms. Journal of the Academy of Marketing Science, 19(1), 43-51.

Deegahawature, M. M. D. R. (2014a). Managers' inclination towards open innovation: effect of job characteristics. European Journal of Business and Management, 6(1), 8-16.

Deegahawature, M. M. D. R. (2014b). Capabilities and implementation of inbound open innovation: Evidence from LMT firms in technologically less advanced countries. European Journal of Business and Management, 6(7), 286-295.

Deegahawature, M. M. D. R. (2014c). The effects of learning orientation on implementation of inbound open innovation in LMT firms. International Journal of Economics, Commerce and Management, 2(5), 1-16.

Drechsler, W., \& Natter, M. (2012). Understanding a firm's openness decisions in innovation. Journal of Business Research, 65(3), 438445.

Edwards, T., Battisti, G., McClendon Jnr, W. P., Denyer, D., \& Neely, A. (2005). Pathways to value: How UK firms can create more value. London: Advanced 
Institute of Management Research.

Elmquist, M., Fredberg, T., \& Ollila, S. (2009). Exploring the field of open innovation. European Journal of Innovation Management 23(3), 326-345.

Essmann , H. E., \& Preez, N. D. (2009). Practical cases of assessing innovation capability with a theoretical model: The process and findings. Retrieved 01 23, 2013, from South African Institute for Industrial Engineering:

http://www.saiie.co.za/ocs/public/ conferences/1/schedConfs/1/prog ram-en_US.pdf\#page $=46$

Ettlie, J. E. (1983). Organizational policy and innovation among suppliers to the food processing sector. Academy of Management Journal, 26(1), 27-44.

Fornell, C., \& Larcker, D. F. (1981). Evaluating structural equation models with unobservable variables and measurement error. Journal of Marketing Research, 18(1), 39-50.

Gatignon, H., \& Xuereb, J. (1997). Strategic orientation of the firm and new product performance. Journal of Marketing Research, 34(1), 77-90.

Hair, J. F., Black, W. C., Babin, B. F., \& Anderson, R. E. (2009). Multivariate data analysis. Prentice Hall: New Jersey.

Hakala, H. (2011). Strategic orientations in management literature: Three approaches to understanding the interaction between market, technology, entrepreneurial and learning orientations. International Journal of Management Reviews, 13(2), 199-217.

Hakala, H., \& Kohtamäki, M. (2011). Configurations of entrepreneurialcustomer- and technology orientation: Differences in learning and performance of software companies. International Journal of Entrepreneurial Behaviour \& Research, 17(1), 64-81.

Hanvanich, S., Sivakumar, K., \& Hult, T. M. (2006). The relationship of learning and memory with organizational performance: The moderating role of turbulence. Journal of the Academy of Marketing Science, 34(4), 600612.

Hatzichronoglou, T. (1997). Revision of the high-technology sector and product classification, OECD science, Technology and industry working papers, 1997/2. Paris: OECD Publishing.

Heidenreich, M. (2009). Innovation patterns and location of European low- and medium-technology industries. Research Policy, 38(3), 483-494.

Herzog, P. (2011). Open and closed innovation: Different cultures for different strategies. Wiesbaden: Gabler Verlag.

Hirsch-Kreinsen, H. (2008). "Lowtechnology": A forgotten sector in innovation policy. Journal of Technology Management \& Innovation, 3(3), 11-20.

Hossain, M., Islam, K. Z., Sayeed, M. A., \& Kauranen, I. (2016). A comprehensive review of open 
innovation literature. Journal of Science \& Technology Policy Management, 7(1), 2-25.

Hossain, M., \& Kauranen, I. (2016). Open innovation in SMEs: A systematic literature review. Journal of Strategy and Management, 7(1), 58-73.

Hult, G. T., Ketchen, D. J., \& Slater, S. F. (2005). Market orientation and performance: An integration of disparate approaches. Strategic Management Journal, 26(12), 1173-1181.

Hung, K.-P., \& Chiang, Y.-H. (2010). Open innovation proclivity, entrepreneurial orientation, and perceived firm performance. International Journal of Technology Management, 52(3/4), 257-274.

Hunt, S. D., \& Morgan, R. M. (1995). Comparative advantage theory of competition. Journal of Marketing, 59(2), 1-15.

Hurley, R. F., \& Hult, G. T. (1998). Innovation market orientation and organizational learning an integration and empirical examination. Journal of Marketing, 62(3), 42-54.

Jaworski, B. J., \& Kohli, A. K. (1993). Market orientation: Antecedents and consequences. Journal of Marketing, 57(3), 53-70.

Kafouros, M. I., \& Forsans, N. (2012). The role of open innovation in emerging economies: Do companies profit from the scientific knowledge of others? Journal of World Business, 47(3), 362-370.
Karo, E., \& Kattel, R. (2010). Is 'open innovation' re-inventing innovation policy for catching-up economies? Tallinn: Tallinn University of Technology.

Kolk, A., \& Püümann, K. (2008). Codevelopment of open innovation strategy and dynamic capabilities as a source of corporate growth. Journal of Economic Literature, 73-83.

Kumar, K., Boesso, G., Favotto, F., \& Menini, A. (2012). Strategic orientation, innovation patterns and performances of SMEs and large companies. Journal of Small Business and Enterprise Development, 19(1), 132-145.

Lee, S., Park, G., Yoon, B., \& Park, J. (2010). Open innovation in SMEs - An intermediated network model. Research Policy, 39(2), 290-300.

Li, J., \& Kozhikode, R. K. (2009). Developing new innovation models: Shifts in the innovation landscapes in emerging economies and implications for global R\&D management. Journal of International Management, 15(3), 328-339.

Li, T., \& Calantone, R. J. (1998). The impact of market knowledge competence on new product advantage: Conceptualization and empirical examination. Journal of Marketing, 62(4), 13-29.

Lichtenthaler, U. (2009). Outbound open innovation and its effect on firm performance: Examining environmental influences. $R \& D$ Management, 39(4), 317-330. 
Makadok, R. (2001). Toward a synthesis of the resource-based view and dynamic-capability views of rent creation. Strategic Management Journal, 22(5), 387 401.

Masa'deh, R., Al-Henzab, J., Tarhini, A., \& Obeidat, B. Y. (2018). The associations among market orientation, technology orientation, entrepreneurial orientation and organizational performance. Benchmarking: An International Journal, 25(8), 3117-3142.

Matsuno, K., \& Mentzer, J. T. (2000). The effects of strategy type on the market orientation-performance relationship. Journal of Marketing, 64(4), 1-16.

Neter, J., Wasserman, W., \& Kutner, M. H. (1990). Applied linear statistical models. Homewood, IL: Irwin.

OECD. (2005). Oslo manual: Guidelines for collecting and interpreting innovation Data, 3/e. Paris, France: OECD Publications.

OECD. (2008). Open innovation in global networks. Paris: OECD Publishing.

Robertson, P., Smith, K. H., \& von Tunzelmann, N. (2009). Innovation in low- and mediumtechnology industries. Research Policy, 38(3), 441-446.

Salavou, H., Baltas, G., \& Lioukas, S. (2004). Organisational innovation in SMEs: The importance of strategic orientation and competitive structure. European
Journal of Marketing, 38(9/10), 1091-1112.

Santamaría, L. S., Nieto, M. J., \& Barge-Gil, A. (2009). Beyond formal R\&D: Taking advantage of other sources of innovation in lowand medium-technology industries. Research Policy, 38(3), 507-517.

Santoro, G., Ferraris, A., Giacosa, E., \& Giovando, G. (2018). How SMEs engage in open innovation: A survey. Journal of the Knowledge Economy, 9(2), 561574.

Smith, M., Busi, M., Ball, P., \& Meer, R. v. (2008). Factors influencing an organisations ability to manage innovation: A structured literature review and conceptual model. International Journal of Innovation Management, 12(4), 655-676.

Song, X. M., \& Parry, M. E. (1997). A cross-national comparative study of new product development processes: Japan and the United States. Journal of Marketing, 61(2), 1-18.

Tarling, R. (2009). Statistical modeling for social researchers: Principles and practice. Oxon: Routledge.

Teece, D. J., Pisano, G., \& Shuen, A. (1997). Dynamic capabilities and strategic management. Strategic Management Journal, 18(7), 509533.

Vrande, V. V., Jong, J. P., Vanhaverbeke, W., \& Rochemont, M. d. (2009). Open innovation in SMEs: Trends, motives and management 
challenges. Technovation, 29(67), 423-437.

West, J., \& Bogers, M. (2017). Open innovation: Current status and research opportunities. Innovation, 19(1), 43-50.

West, J., Vanhaverbeke, W., \& Chesbrough, H. (2006). Open innovation: A research agenda. In H. Chesbrough, W. Vanhaverbeke, \& J. West, Open innovation: Researching a new paradigm (pp. 285-307). Oxford: Oxford University Press.

Wiklund, J., \& Shepherd, D. (2003). Knowledge-based resources, entrepreneurial orientation, and the performance of small and medium-sized businesses. Strategic Management Journal, 24(13), 1307-1314.
Zhou, K. Z., \& Wu, F. (2010). Technological capability, strategic flexibility, and product innovation.

Strategic Management Journal, 31(5), 547561.

Zhou, K. Z., Yim, C. K., \& Tse, D. K. (2005). The effects of strategic orientations on technology- and market-based breakthrough innovations. Journal of Marketing, 69(2), 42-60. 